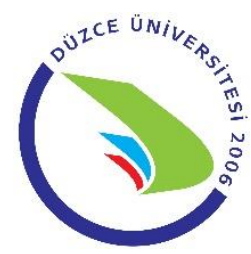

\title{
Assessment of Adherence to the Mediterranean Diet and Behaviors of Fruit and Vegetable Consumption in Adolescents
}

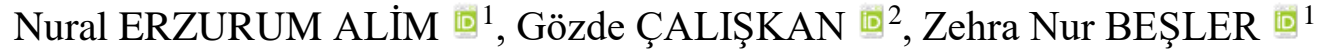

\begin{abstract}
Aim: This study aimed to investigate the adherence of adolescents to the Mediterranean diet and to determine their behaviors of fruit and vegetable consumption.

Methods: The study involved 487 adolescents studying at high school in Ankara, Turkey. The study data were collected by using the questionnaire form involving general characteristics, anthropometric measurements, dietary habits, the Mediterranean Diet Quality Index (KIDMED), and the Scale of Processes of Change for Fruit and Vegetable Consumption (SPCFVC). The SPCFVC has two sub-dimensions, cognitive and behavioral. Independent Sample-t test, ANOVA, Mann-Whitney-U test, Kruskal-Wallis-H test, Pearson $\chi 2$ - test, and Spearman correlation coefficient were used to analyze the data.

Results: Among the participants, $51.5 \%$ were females and $48.5 \%$ were males. Of these, $11.1 \%$ were overweight and $1.9 \%$ were obese. The mean KIDMED, total SPCFVC, and behavioral SPCFVC scores were higher among males than females $(\mathrm{p}<0.05)$. It was found out that $31.6 \%$ of the males had a low, 55.6\% had a moderate, and $12.8 \%$ had a good diet quality, while $43.4 \%$ of the females had a low, $48.2 \%$ had a moderate, and $8.4 \%$ had a good diet quality according to KIDMED. The adolescents who smoked, skipped breakfast, had a low number of main meals, and were not informed about healthy diet had statistically lower mean KIDMED and SPCFVC scores $(\mathrm{p}<0.05)$.

Conclusion: The adherence of adolescents to the Mediterranean diet was low and moderate, males better adhered to the Mediterranean diet, and they could adapt to changes related to fruit and vegetable consumption more easily.

Keywords: Adolescent; obesity; diet mediterranean; fruit; vegetables.
\end{abstract}

\section{Adölesanlarda Akdeniz Diyetine Uyum ile Meyve ve Sebze Tüketim Davranışlarının Değerlendirilmesi}

\section{ÖZ}

Amaç: Bu çalışma, adölesanların Akdeniz diyetine uyumlarının belirlenmesi ve meyve sebze tüketim davranışlarının değerlendirilmesi amacıyla yapılmıştır.

Yöntem: Bu çalışma Ankara ilinde lise öğrenimi gören 487 adölesan ile gerçekleştirilmiştir. Çalışmanın verileri; genel özellikler, antropometrik ölçümler, beslenme alışkanlıkları, Akdeniz Diyet Kalite İndeksi (KIDMED) ile Meyve ve Sebze Tüketimi Değişim Süreci Ölçeği (MSTDÖ)'ni içeren anket formu kullanılarak toplanmıştır. MSTDÖ ölçeğinin bilişsel ve davranışsal olarak iki alt boyutu vardır. Verilerin analizinde Independent Sample-t test, ANOVA, MannWhitney-U test, Kruskal-Wallis-H testi ve Pearson $\chi 2$ - testi ile Spearman korelasyon katsayısı kullanılmıştır.

Bulgular: Çalışmaya katılan bireylerin \%51,5'i kadın, \%48.5'i erkek öğrencilerden oluşmaktadır. Adölesanların \%11,1'inin fazla kilolu ve \%1.9'unun obez olduğu saptanmıştır. KIDMED, MSTDÖ toplam ve MSTDÖ davranışsal alt boyutu puan ortalamalarının erkeklerde kadınlara göre daha yüksek olduğu belirlenmiştir $(\mathrm{p}<0,05)$. Erkeklerin KIDMED'e göre \%31,6'sının düşük, \%55,6'sının orta, \%12,8'inin iyi; kadınların ise \%43,4'ünün düşük, \%48,2'sinin orta, \%8,4'ünün iyi diyet kalitesine sahip olduğu saptanmıştır. Sigara kullanan, kahvaltı öğününü atlayan, ana öğün sayısı düşük olan ve sağlıklı beslenme bilgisine sahip olmayan adölesanların KIDMED ve MSTDÖ puan ortalamalarının

1 Ankara Yıldırım Beyazıt University, Faculty of Health Sciences, Department of Nutrition and Dietetics, 06760 Ankara, Turkey

2 Muş Alparslan University, Faculty of Health Sciences, Department of Nutrition and Dietetics, 49250 Mus, Turkey

Sorumlu Yazar / Corresponding Author: Nural Erzurum ALIM, e-mail: nalim@ybu.edu.tr

Geliş Tarihi / Received: 11.06.2020, Kabul Tarihi / Accepted: 07.12.2021 
istatistiksel olarak daha düşük olduğu belirlenmiştir $(\mathrm{p}<0,05)$.

Sonuç: Adölesanların Akdeniz diyet uyumlarının düşük ve orta düzeyde olduğu, erkeklerin Akdeniz diyetine daha iyi uyum gösterdiği ve meyve sebze tüketimleri ile ilgili değişikliklere daha kolay uyum sağlayabildikleri bulunmuştur.

Anahtar Kelimeler: Adölesan; obezite; Akdeniz diyeti; meyve; sebze.

\section{INTRODUCTION}

Adolescence is defined as the transition period between the onset of puberty and the achievement of selfsufficiency. The World Health Organization (WHO) regards individuals aged 10-19 years as adolescent. This period is divided into three phases as early adolescence (10-14 years), late adolescence (15-19 years), and young adulthood (20-24 years) $(1,2)$. Adolescence is a period crucial for the composition of body and the occurrence of obesity in adult life. This might be caused by alterations of hormones that affect the regulation of satiety, appetite, and the distribution of fat which occur in puberty (3).

A dramatic increase was observed in the rate of overweight and the prevalence of obesity in children and adolescents aged 5-19 years, from only 4\% recorded in 1975 to more than $18 \%$ in 2016 . This increase occurred among males and females in a similar way. The 2016 data showed that overweight was observed among $18 \%$ of females and $19 \%$ of males (4). The data of the Childhood Obesity Surveillance Initiative of Turkey (COSI-TUR 2016) show that $14.6 \%$ of the children in the $7-8$ age group in Turkey were overweight and $9.9 \%$ were obese (5). It is possible that dietary habits that develop in adolescence continue throughout adult life. Therefore, serious consideration has been given to improving dietary habits at a young age (6). Getting the young acquire healthy dietary habits during adolescence has positive effects on preventing chronic diseases in adulthood and maintaining a healthy life (7). Among the most significant markers of the quality of diet is regular consumption of fruit and vegetables (8). Daily consumption of adequate amounts of fruit and vegetables is effective in the promotion of health and the prevention of chronic diseases (9). Insufficient fruit and vegetable intake is greatly prevalent among individuals from all age groups, adolescents in particular. Low consumption often begins early in life (10). The findings of the National Youth Physical Activity and Nutrition Study carried out in 2010 indicated that the daily consumption of fruit was less than one serving in $28.5 \%$ of adolescents and the daily consumption of vegetables was less than one serving in $33.2 \%$ of adolescents. This consumption style brings about concerns because unhealthy dietary habits that adolescents adopt may continue during adulthood (11). The promotion of good health and carrying out the recommendations concerning adequate fruit and vegetable consumption during adolescence can create positive consequences for long-term health (6). The Food and Agriculture Organization (FAO) and WHO recommend that individuals consume at least $400 \mathrm{~g}$ of fruit and vegetables per day (except for potatoes and similar starchy tubers), which equals to $\geq 2$ servings of fruit and $\geq 3$ servings of vegetables, in order to prevent chronic diseases (12). Studies carried out in Europe and North America indicate that most of children and adolescents fail to reach these recommendations (13-15). Originally defined by Angel Keys, the Mediterranean diet mainly consists of different types of fruit and vegetables and the consumption of whole-grain food. Esposito et al. (16) evaluated 16 randomized controlled studies to determine the effect of the Mediterranean diet on body weight. The study results revealed that the consumption of the Mediterranean diet caused a greater weight loss compared to the control diet. In another study, good adherence to the Mediterranean diet in adolescents was related to a $30 \%$ decrease in the likelihood of overweight or obesity (17). Behavior change programs are used to increase the amount of fruit and vegetable consumption in adolescents (18). It is necessary to determine cognitive and behavioral processes that might affect fruit and vegetable consumption of adolescents so that they guide the preparation of these programs. These processes of change help understand which experiences individuals use and change their behaviors and they guide the initiatives to increase fruit and vegetable consumption (19). Dietary habits that will last for a lifetime develop during adolescence. Therefore, it is important to determine the dietary habits of adolescents and get them acquire healthy dietary habits. This study aimed to determine adherence to the Mediterranean diet, which is a healthy dietary pattern, and behaviors of fruit and vegetable consumption in adolescents.

\section{MATERIAL AND METHODS}

\section{Sample}

This cross-sectional and descriptive study was carried out in January-February 2020 on 487 adolescents (251 females, 236 males) aged between 15-18 years studying at high school in Ankara. As a result of the power analysis made by using the $\mathrm{G} *$ Power 3.0.1 program; With $80 \%$ power, $5 \%$ margin of error and $d=0.2858$ effect size, at least 388 samples in total were found sufficient ( $\mathrm{n}$ females $=194 ; \mathrm{n}$ males $=194$ ). The haphazard sampling method was used in sample selection.

\section{Data Collection Tools \\ Questionnaire form}

A questionnaire form was applied to the participants, which consisted of 37 items about socio-demographic characteristics, anthropometric measurements, the education level of parents, and dietary habits and information with the help of trained dieticians through face-to-face interview technique. The Mediterranean Diet Quality Index (KIDMED) was used to determine dietary habits. The Scale of Processes of Change for Fruit and Vegetable Consumption (SPCFVC) was used to determine whether individuals were ready to make changes their risky behaviors in the positive direction by getting them acquire healthy behaviors.

\section{The Mediterranean Diet Quality Index (KIDMED)}

The Mediterranean Diet Quality Index (KIDMED) consists of 16 items with 'Yes' and 'No' responses, of which 12 are positive and 4 are negative items. Those who answer 'Yes' to positive items receive +1 point, and those who answer 'Yes' to negative items receive -1 point. At the end, scores ranging between $0-12$ are 
obtained, and these scores are classified as good $(\geq 8$ points), moderate ( $4-7$ points), and low ( $\leq 3$ points) in terms of the quality of the Mediterranean diet (20).

Scale of Processes of Change for Fruit and Vegetable Consumption (SPCFVC)

The Turkish validity and reliability of the Scale of Processes of Change for Fruit and Vegetable Consumption (SPCFVC), which was developed by Di Noia et al. (21), was carried out by Erol, et al. in 2016 (19). SPCFVC is a five Likert-type scale consisting of the options "Completely disagree", "Disagree", "Neutral", "Partly Agree", and "Completely agree". The scale has two subscales and consists of 19 items. There are 7 items in the cognitive subscale and 12 items in the behavioral subscale. The highest score that can be obtained from the cognitive subscale is 35 and the lowest score is seven, while the highest score that can be obtained from the behavioral subscale is 60 and the lowest score is 12 . High scores obtained from the subscales indicate that the likelihood of being successful in change increases. The reliability of the scale was measured to be 0.79 for the cognitive processes subscale and 0.90 for the behavioral processes.

\section{Anthropometric measurements}

Body weight and height of all the individuals were measured. The body mass indices (BMI) of the participants were calculated using the formula of body weight/(body height $)^{2}$. In the sample, 10 individuals did not want to state their body weight and/or body height.

\section{Research Ethics}

The study was approved by Ethics Committee of Ankara Y1ldırım Beyazıt University (Project No: 2019-559) on December 12, 2019 and it was carried out in accordance with the Declaration of Helsinki. Before the study, the required institutional permissions were obtained. The study aims were explained to the students and written informed consent was obtained from the students who participated in the study. This study has been prepared in accordance with the rules of research and publication ethics.

\section{Statistical Analysis}

Statistical analyses were performed using Statistical Package for the Social Sciences (IBM SPSS Statistics 24) package software. Frequency tables and descriptive statistics were used to interpret the findings. In analysing the normality assumptions of the data; KolmogorovSmirnov and Shapiro-Wilk test statistics were used according to the sample sizes of the groups. In addition, Q-Q plot and skewness-kurtosis values were also examined.

Parametric methods were employed for measurement values compatible with normal distribution. In order to decide on the post-hoc test to be used after ANOVA, the homogeneity of the variances of the group distributions was tested first with the Levene's test and it was determined that the variances were homogeneous, and "Tukey" pairwise comparisons were used. In line with parametric methods, the ANOVA (F-table value) was used for the comparison of three or more independent groups with the measurement values.

Non-parametric methods were employed for measurement values that were not compatible with normal distribution. In line with non-parametric methods, the Mann-Whitney U test (Z-table value) was used for the comparison of two independent groups with the measurement values and the Kruskal-Wallis $H$ test $(\chi 2-$ table value) was used for the comparison of three or more independent groups with the measurement values. Bonferroni-corrected Mann Whitney-U test was used for pairwise comparisons to determine which groups caused the significant difference found after the Kruskal-Wallis$\mathrm{H}$ test. The Pearson $\chi^{2}$ - test was used to investigate the relationships of two qualitative variables. The Spearman's correlation coefficient was used to examine the association of measurement values without a normal distribution.

\section{RESULTS}

Table 1 shows some socio-demographic characteristics about adolescents, including sex, age, cigarette use, education level of parents, skipping meals, the number of snacks/main meals, the attitudes of healthy diet, and whether they had information about the topic. Of the individuals who participated in the study, $51.5 \%$ were females and $48.5 \%$ were males. The mean age was 15.91 \pm 1.06 .

Table 1. Socio-demographic characteristics of adolescents $(n=487)$

\begin{tabular}{|c|c|c|c|}
\hline \multicolumn{2}{|l|}{ Variables } & $\mathbf{n}$ & $\%$ \\
\hline \multirow{2}{*}{ Sex } & Females & 251 & 51.5 \\
\hline & Males & 236 & 48.5 \\
\hline \multirow[t]{4}{*}{ Age } & 15 & 244 & 50.1 \\
\hline & 16 & 95 & 19.5 \\
\hline & 17 & 93 & 19.1 \\
\hline & 18 & 55 & 11.3 \\
\hline \multirow{2}{*}{$\begin{array}{l}\text { Cigarette } \\
\text { use }\end{array}$} & Never smoked & 400 & 82.1 \\
\hline & Yes/Sometimes/Quit & 87 & 17.9 \\
\hline \multirow{5}{*}{$\begin{array}{l}\text { Mother's } \\
\text { education } \\
\text { level* }\end{array}$} & Illiterate & 6 & 1.2 \\
\hline & Primary school & 146 & 30.4 \\
\hline & Secondary school & 139 & 28.9 \\
\hline & High school & 151 & 31.4 \\
\hline & College or university & 39 & 8.1 \\
\hline \multirow{4}{*}{$\begin{array}{l}\text { Father's } \\
\text { education } \\
\text { level* }\end{array}$} & Primary school & 86 & 17.9 \\
\hline & Secondary school & 140 & 29.2 \\
\hline & High school & 175 & 36.4 \\
\hline & College or university & 79 & 16.5 \\
\hline \multirow{3}{*}{$\begin{array}{l}\text { Skipping } \\
\text { meals }\end{array}$} & Breakfast & 189 & 58.9 \\
\hline & Lunch & 98 & 30.5 \\
\hline & Dinner & 34 & 10.6 \\
\hline \multirow[t]{3}{*}{ Main meal } & 1 & 41 & 8.4 \\
\hline & 2 & 186 & 38.2 \\
\hline & 3 & 260 & 53.4 \\
\hline \multirow[t]{3}{*}{ Snack } & 1 & 188 & 38.6 \\
\hline & 2 & 178 & 36.6 \\
\hline & $3+$ & 121 & 24.8 \\
\hline \multirow{2}{*}{$\begin{array}{l}\text { I have a } \\
\text { healthy diet }\end{array}$} & Yes & 184 & 37.8 \\
\hline & No & 303 & 62.2 \\
\hline \multirow{2}{*}{$\begin{array}{l}\text { I have } \\
\text { information } \\
\text { about } \\
\text { healthy diet }\end{array}$} & Yes & 387 & 79.5 \\
\hline & No & 100 & 20.5 \\
\hline \multirow{4}{*}{$\begin{array}{l}\text { BMI } \\
\text { group* }\end{array}$} & Weak $(\leq 18.49)$ & 85 & 17.8 \\
\hline & $\begin{array}{l}\text { Normal-weight (18.5 - } \\
24.9)\end{array}$ & 330 & 69.2 \\
\hline & Overweight (25-29.9) & 53 & 11.1 \\
\hline & Obese $(\geq 30)$ & 9 & 1.9 \\
\hline
\end{tabular}

*There were individuals who did not want to share the educational background and height-weight information of their parents.

BMI: Body Mass Index, n: number, \%: percent 
Table 2 presents the total mean scores of adolescents with respect to sex from the Scale of Processes of Change for Fruit and Vegetable Consumption (SPCFVC) and its subscales and from KIDMED. It was found out that the SPCFVC, the behavioral subscale of SPCFVC, and KIDMED scores were higher among males than females $(\mathrm{Z}=-2.965 ; \mathrm{p}=0.003 ; \mathrm{Z}=-3.092 ; \mathrm{p}=0.002 ; \mathrm{Z}=-2.905$; $\mathrm{p}=0.004$, respectively).
Therefore, it was figured out that the diet quality of males was higher, and they could more easily adapt to changes related to fruit and vegetable consumption in behavioral aspect.

Table 2. The SPCFVC and KIDMED mean, standard deviation, and interquartile range values of individuals according to sexes

\begin{tabular}{|c|c|c|c|c|c|c|c|}
\hline \multirow[b]{2}{*}{ Variable } & \multicolumn{2}{|c|}{ Females $(n=244)$} & \multicolumn{2}{|c|}{ Males $(n=228)$} & \multicolumn{2}{|c|}{ Total $(n=472)$} & \multirow[b]{2}{*}{$\mathbf{p}^{*}$} \\
\hline & $\overline{\mathbf{X}} \pm$ S. S. & $\begin{array}{l}\text { Median } \\
\text { [IQR] }\end{array}$ & $\overline{\mathbf{X}} \pm \mathbf{S} . \mathbf{S}$ & $\begin{array}{l}\text { Median } \\
\text { [IQR] }\end{array}$ & $\overline{\mathbf{X}} \pm S . S$. & $\begin{array}{l}\text { Media } \\
\text { n } \\
{[\mathrm{IQR}]}\end{array}$ & \\
\hline SPCFVC Cognitive & $21.39 \pm 5.44$ & $\begin{array}{l}21.0 \\
{[7.0]}\end{array}$ & $22.06 \pm 6.68$ & $\begin{array}{l}22.0 \\
{[9.0]}\end{array}$ & $21.72 \pm 6.07$ & $\begin{array}{l}22.0 \\
{[8.0]}\end{array}$ & 0.166 \\
\hline SPCFVC Behavioral & $25.64 \pm 8.95$ & $\begin{array}{l}25.0 \\
{[12.0]}\end{array}$ & $29.16 \pm 11.77$ & $\begin{array}{l}29.0 \\
{[17.0]}\end{array}$ & $27.34 \pm 10.55$ & $\begin{array}{l}26.0 \\
{[15.0]}\end{array}$ & 0.002 \\
\hline SPCFVC Total & $47.03 \pm 12.60$ & $\begin{array}{l}46.0 \\
{[16.0]}\end{array}$ & $51.22 \pm 16.46$ & $\begin{array}{l}51.5 \\
{[19.8]}\end{array}$ & $49.06 \pm 14.73$ & $\begin{array}{l}48.0 \\
{[18.0]}\end{array}$ & 0.003 \\
\hline KIDMED & $3.92 \pm 2.68$ & $\begin{array}{l}4.0 \\
{[4.0]}\end{array}$ & $4.61 \pm 2.45$ & $\begin{array}{l}5.0 \\
{[3.0]}\end{array}$ & $4.25 \pm 2.59$ & $\begin{array}{l}4.0 \\
{[3.0]}\end{array}$ & 0.004 \\
\hline
\end{tabular}

*In data without a normal distribution, the Mann-Whitney $U$ test (Z-table value) statistics were used for the comparison of two independent groups with the measurement values.

SPCFVC: Scale of Processes of Change for Fruit and Vegetable Consumption, KIDMED: Mediterranean Diet Quality Index, IQR: Interquartile range, $\mathrm{X}^{-} \mathrm{S}$.S.: Mean \pm Standard Deviation, $\mathrm{n}$ : number

Table 3 presents the assessment of adolescents' diet quality with respect to sex and KIDMED scores. A statistically significant relationship was detected between sex and KIDMED score groups $(\mathrm{p}<0.05)$. Post-hoc was performed using standardized residuals. It was found out that $48.2 \%$ of females had a moderate, $43.4 \%$ had a low, and $8.4 \%$ had a good diet quality. Among the males, on the other hand, 31.6\% had a low, 55.6\% had a moderate, and $12.8 \%$ had a good diet quality. Low and medium KIDMED scores are predominantly seen in females, while good KIDMED scores are mainly seen in males. At the end of the Post-hoc test, it was seen that the significant relationship arose from females and males with a low diet quality $(\mathrm{p}=0.007)$.

Table 3. The assessment of adolescents' diet quality with respect to their KIDMED scores

\begin{tabular}{|l|l|l|l|l|l|l|l|}
\hline & \multicolumn{2}{|l|}{ Females $(\mathbf{n}=\mathbf{2 5 1})$} & \multicolumn{2}{l|}{ Males $(\mathbf{n}=\mathbf{2 3 4})$} & \multicolumn{2}{|l|}{ Total $(\mathbf{n}=\mathbf{4 8 5})$} & $\mathbf{p}^{*}$ \\
\hline KIDMED & $\mathbf{n}$ & $\mathbf{\%}$ & $\mathbf{n}$ & $\mathbf{\%}$ & $\mathbf{n}$ & $\mathbf{\%}$ & \\
\hline Low $\leq \mathbf{3}$ & 109 & 43.4 & 74 & 31.6 & 183 & 37.7 & \multirow{2}{*}{$\mathbf{0 . 0 1 8}$} \\
\hline Moderate 4-7 & 121 & 48.2 & 130 & 55.6 & 251 & 51.8 & \\
\hline Good $\geq \mathbf{8}$ & 21 & 8.4 & 30 & 12.8 & 51 & 10.5 & \\
\hline
\end{tabular}

* The Pearson $\chi 2$-test was used to investigate the relationshipps of two qualitative variables.

KIDMED: Mediterranean Diet Quality Index, n: number, \%: percent

Table 4 presents the comparison of the KIDMED and SPCFVC scores of adolescents with regard to age, cigarette use, education level of parents, skipping meals, the number of meals, the status of healthy diet, and BMI groups.

Statistically significant differences were detected in terms of the total, cognitive, and behavioral SPCFVC and KIDMED scores $(\mathrm{p}<0.05)$ in terms of smoking. The total, cognitive, and behavioral SPCFVC and KIDMED scores of those who never smoke statistically significantly higher than those who smoke, occasionally smoke or who quit smoking.

There are no statistically significant differences in the total, cognitive, and behavioral SPCFVC and KIDMED scores in terms of the parents' educational background $(\mathrm{p}>0.05)$.
The total KIDMED and SPCFVC scores of those who do not skip breakfast were statistically significantly higher than those who did $(p<0.05)$. There are no statistically significant differences in the total, cognitive, and behavioral SPCFVC and KIDMED scores in terms of skipping lunch and dinner ( $\mathrm{p}>0.05)$.

The KIDMED scores of those who had 2 and 3 main meals were statistically significantly higher compared to those who had 1 main meal. In the same token, it was observed that the KIDMED scores of those who had 3 main meals were statistically significantly higher compared to those who had 2 main meals $(p<0.05)$. When it comes to the total and behavioral SPCFVC scores, those who had 3 main meals had statistically significantly higher scores than those who had 1 main meal $(\mathrm{p}<0.05)$. There were no statistically significant differences in the cognitive SPCFVC scores ( $p>0.05)$. 
As for the number of snacks, the total SPCFVC scores of those who had 2 snacks were statistically significantly higher compared to those who had 1 snack. The behavioral SPCFVC scores of those who had 2 snacks were statistically significantly higher than those who had 1 snack $(\mathrm{p}<0.05)$. There were no statistically significant differences in the cognitive SPCFVC and KIDMED scores in terms of the number of snacks $(\mathrm{p}>0.05)$.

Table 4. Comparison of adolescents' socio-demographic characteristics and dietary habits with respect to the KIDMED and SPCFVC scores

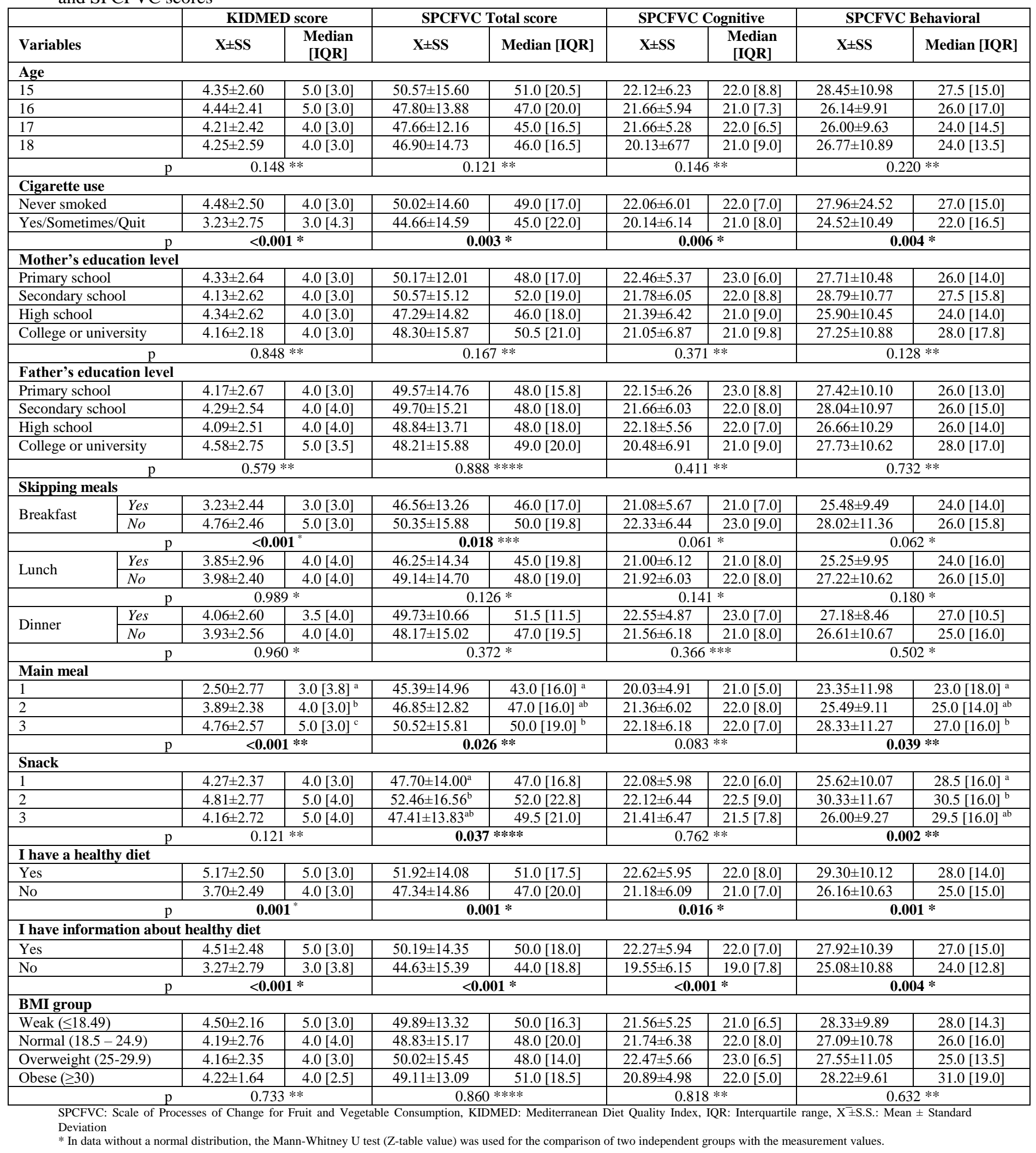


** In data without a normal distribution, the Kruskal-Wallis $\mathrm{H}$ test ( $\chi 2$-table value) statistics were used for three or more independent groups.

*** In data with a normal distribution, the independent sample $\mathrm{t}$-test (t-table value) was used for the comparison of two independent groups with the measurement values.

**** In data with a normal distribution, ANOVA (F-table value) was used to compare the measurement values of three or more independent groups in the data with normal distribution

The correlation analysis between the scores of KIDMED and SPCFVC of adolescents is presented in Table 5. A positive, weak, and statistically significant relationship was detected between the KIDMED scores of females and the cognitive, behavioral, and total SPCFVC scores $(\mathrm{p}<0.05)$. A positive, weak, and statistically significant relationship was detected between the KIDMED scores of males and the cognitive, behavioral, and total SPCFVC scores $(\mathrm{p}<0.05)$. A positive, weak, and statistically significant relationship was detected between the KIDMED scores of the whole sample and the cognitive, behavioral, and total SPCFVC scores $(\mathrm{p}<0.05)$.

Table 5. Correlation analysis between KIDMED scores and SPCFVC scores in terms of sex

\begin{tabular}{|l|l|l|l|l|l|l|}
\hline & \multicolumn{2}{|l|}{ Females $(\mathrm{n}=251)$} & \multicolumn{2}{l|}{ Males $(\mathrm{n}=236)$} & \multicolumn{2}{l|}{ Total $(\mathrm{n}=487)$} \\
\hline & $\mathrm{r}^{*}$ & $\mathrm{p}$ & $\mathrm{r}$ & $\mathrm{p}$ & $\mathrm{r}$ & $\mathrm{p}$ \\
\hline SPCFVC Cognitive & 0.269 & $<0.001$ & 0.196 & 0.003 & 0.250 & $<0.001$ \\
\hline SPCFVC Behavioral & 0.359 & $<0.001$ & 0.188 & 0.004 & 0.289 & $<0.001$ \\
\hline SPCFVC Total & 0.362 & $<0.001$ & 0.215 & 0.001 & 0.303 & $<0.001$ \\
\hline
\end{tabular}

* The Spearman's correlation coefficient was used to examine the relationship of two qualitative variables.

KIDMED: Mediterranean Diet Quality Index, SPCFVC: Scale of Processes of Change for Fruit and Vegetable Consumption

\section{DISCUSSION}

The main purpose of adolescent individuals' diet is to maintain healthy growth and development with regard to body and soul, and in social terms. Growth and development were achieved by an adequate and balanced diet. Furthermore, resistance against diseases is strengthened. Additionally, dietary habits acquired during adolescence and childhood have an important role in increasing school success, developing cognitive functions, ensuring bone development, and preventing some acute and chronic disease that might appear in advanced ages. Acquiring wrong dietary habits during these periods may lead to permanent damages and negatively affect health for a lifetime (22-24).

This study, which was carried out with 487 volunteer high school students, 251 females $(51.5 \%)$ and 236 males (48.5\%) aged between 15-18 years, assessed adolescents' adherence to the Mediterranean diet and the process of change of fruit and vegetable consumption and determined the related factors. According to the TNHS 2010 data, the most comprehensive nutrition survey carried out in Turkey, $1.5 \%$ of individuals in the $15-18$ age group were weak, $16.6 \%$ were normal-weight, $13.5 \%$ was overweight, and $8.3 \%$ were obese (25). Based on the BMI values, $17.8 \%$ of the participants were weak, $69.2 \%$ were normal-weight, $11.1 \%$ were overweight, and $1.9 \%$ were obese. When the TNHS 2010 data about adolescents' status of skipping meals were examined, it was seen that $17.3 \%$ of the males and $24 \%$ of the femaless aged between 15-18 years skipped breakfast. It was reported that a decrease was observed in the rate of skipping breakfast among males and females with advancing age. It was found that the rate of skipping lunch was $10 \%$ among males and $15.3 \%$ among females in the 15-18 age group. Furthermore, the rate of skipping dinner was $2.7 \%$ among males and $8.3 \%$ among females (25). In our study, on the other hand, it was revealed that $58.9 \%$ of individuals skipped breakfast, $30.5 \%$ skipped lunch, and $10.6 \%$ skipped dinner. It was seen that $24.8 \%$ of individuals had three or more snacks. The data of TNHS 2010 indicate that $4.4 \%$ of individuals consumed one main meal, $22.6 \%$ consumed two main meals, and
$71.7 \%$ consumed three main meals (25). In our study, however, $8.4 \%$ of individuals consumed one, $38.2 \%$ consumed two, and $53.4 \%$ consumed three main meals. When the snack consumption of individuals was examined, it was seen that $38.6 \%$ consumed one, $36.6 \%$ consumed two, and $24.8 \%$ consumed three snacks.

It was found out that the mean scores of SPCFVC, the behavioral subscale of SPCFVC, and KIDMED were higher among males than females $(Z=-2.965 ; \mathrm{p}=0.003$; $\mathrm{Z}=-3.092 ; \mathrm{p}=0.002 ; \mathrm{Z}=-2.905 ; \mathrm{p}=0.004$, respectively). Therefore, it was determined that the diet quality of males was higher, and they could more easily adapt to changes related to fruit and vegetable consumption especially in behavioral aspect. In a study carried out in 2017 by Aygün and Muslu (26), it was found that the mean scores of females were statistically significant and higher than the scores of males in cognitive and behavioral process subscales. The majority of studies report that females have habits of consuming more fruit and vegetables than males in adolescence $(27,28)$. The Mediterranean diet is a dietary pattern with protective effects against numerous diseases like cardiovascular diseases, obesity, diabetes, and cancer, which consists of healthy dietary habits. A statistically significant relationship was detected between sex and KIDMED score groups $(\mathrm{p}<0.05)$. It was found out that $48.2 \%$ of females had a moderate, $43.4 \%$ had a low, and $8.4 \%$ had a good diet quality. Among the males, on the other hand, $31.6 \%$ had a low, $55.6 \%$ had a moderate, and $12.8 \%$ had a good diet quality. Low and medium KIDMED scores are predominantly seen in females, while good KIDMED scores are mainly seen in males. Serra-Maje et al. (20) reported that the number of males who had moderate and low scores was higher than girls $(50.2 \%$ vs $49.9 \%$; $5.9 \%$ vs $4.7 \%$, respectively), but more girls had high scores than males (45.4\% vs $43.9 \%)$. In the study by Sahingoz and Sanlier (29), the number of males who had moderate scores was higher than females (61.5\% vs $56.7 \%)$; however, the number of girls who had high and low score was higher than males $(24.9 \%$ vs $21.1 \% ; 18.4 \%$ vs $17.4 \%)$. The total, cognitive, and behavioral SPCFVC and KIDMED scores of those who never smoke statistically significantly higher than those 
who smoke, occasionally smoke or who quit smoking. Studies show that adherence to the Mediterranean diet is significantly correlated with being a non-smoker $(30,31)$. The study carried out by Peng et al. (31) with 5268 adolescents aged 11-19 years reported that the KIDMED scores of smoking males were significantly lower. The KIDMED and SPCFVC scores of those who thought they had a healthy diet and had information about healthy diet were significantly higher than those who thought they did not have a healthy diet and did not have information about healthy diet. These individuals having higher SPCFVC scores and a greater adherence to the Mediterranean diet can generally be explained with the fact that they adopted a healthier lifestyle.

In our study, the KIDMED scores of those who had 2 and 3 main meals were statistically significantly higher compared to those who had 1 main meal. Similarly, it was observed that the KIDMED scores of those who had 3 main meals were statistically significantly higher compared to those who had 2 main meals $(\mathrm{p}<0.05)$. When it comes to the total and behavioral SPCFVC scores, those who had 3 main meals had statistically significantly higher scores than those who had 1 main meal $(\mathrm{p}<0.05)$. In Sahingoz and Sanlier (29), a difference was detected between the KIDMED scores of adolescents who ate two meals and those who ate $3 / 4$ meals a day. It was determined that both the KIDMED and SPCFVC scores of adolescents who did not skip breakfast were higher than those who did. This is similar to the results of Sahingoz and Sanlier (29), which was carried out with 890 adolescents. Del Mar et al. (32) showed that the adolescents who frequently skipped breakfast and who said that they had less than three meals daily and consumed snacks received the lowest KIDMED score. It is thought that a high number of meals and not skipping meals can increase the variety of foods in the diet and positively affect the adherence to the Mediterranean diet and the behavior of fruit and vegetable consumption.

The age, the education level of parents, and the mean scores received from KIDMED and the total SPCFVC, cognitive and behavioral process subscales were not different across the groups. Aygün and Muslu (26) found out that students whose parents had high school and university education obtained higher mean scores from SPCFVC cognitive and behavioral process subscales. In another study, it was reported that as the mother's level of education increased, the KIDMED scores of adolescents rose significantly. However, no differences were detected between father's level of education and the KIDMED scores (29). This difference can be explained with the fact that the education level of mother and father was lower in our study than other studies.

A positive, weak, and statistically significant relationship was detected between the KIDMED scores of girls and the cognitive, behavioral, and total SPCFVC scores $(\mathrm{p}<0.05)$. A positive, weak, and statistically significant relationship was detected between the KIDMED scores of males and the cognitive, behavioral, and total SPCFVC scores $(\mathrm{p}<0.05)$. A positive, weak, and statistically significant relationship was detected between the KIDMED scores of the whole sample and the cognitive, behavioral, and total SPCFVC scores $(p<0.05)$. This linear association between adherence to the KIDMED index and SPCFVC can be based on the fact that four of the 16 items involved in the KIDMED index investigate fruit and vegetable consumption. Therefore, increasing fruit and vegetable consumption among adolescents by encouraging behavior changes is of great importance as it can enhance adherence to the Mediterranean diet.

This study was conducted only in the province of Ankara and thus might not represent all of the Turkish adolescent population, which can be considered as the study limitation. Nevertheless, it is among the strengths of our study that the sample chosen to represent the adolescent group was large and the socio-demographic factors of the participants were included in the study.

\section{CONCLUSION}

It was seen in the study that the adherence of adolescents to the Mediterranean diet was at low and moderate level. It was also found that males showed a better adherence to the Mediterranean diet and their SPCFVC scores were higher. It was determined that factors such as cigarette use, skipping meals, main meals, snacks, and having information about healthy diet affected the Mediterranean Diet Quality Index and fruit and vegetable consumption behaviors. Dietetics should be given more importance in school curricula and students' access to fruit and vegetables should be facilitated in order to have adolescents acquire healthy dietary habits.

Authors's Contributions: Idea/Concept: N.E.A., G. Ç., Z. N. B.; Design: N.E.A., G. Ç., Z. N. B.;Data Collection and/or Processing: N.E.A., G. Ç., Z. N. B.; Analysis and/or Interpretation: N.E.A., G. Ç., Z. N. B.; Literature Review: N.E.A., G. Ç., Z. N. B.; Writing the Article: N.E.A., G. Ç., Z. N. B.; Critical Review: N.E.A., G. Ç., Z. N. B.

\section{REFERENCES}

1. World Health Organization [Internet]. Switzerland: Improving Adolescent Health and Development Inc; 2001 [Updated: 2001; Cited: 2020 Apr 3]. Available from:https://www.who.int/maternal_child_adolescent/ documents/frh_adh_98_18/en/.

2. Patton GC, Sawyer SM, Santelli JS, Ross DA, Afifi R, Allen NB, et al. Our future:A Lancet commission on adolescent health and wellbeing. The Lancet. 2016; 387(10036): 2423-78.

3. Diethelm K, Jankovic N, Moreno LA, Huybrechts I, De Henauw S, De Vriendt T, et al. Food intake of European adolescents in the light of different foodbased dietary guidelines: results of the HELENA (Healthy Lifestyle in Europe by Nutrition in Adolescence) Study. Public Health Nutrition. 2012; 15(3): 386-98.

4. World Health Organization [Internet]. Switzerland: World Health Organization; Inc; 2020 [Updated: 2020 April 1; Cited: 2020 Apr 9]. Available from: https://www.who.int/news-room/fact sheets/detail/obesity-and-overweight.

5. Özcebe H, Bosi TB, Yardım N. Türkiye Çocukluk Çağ1 (İlkokul ikinci sınıf öğrencileri) Şişmanlık Araştırması: COSI-TUR 2016. Ankara: Efe Matbaacilik; 2017.

6. Vereecken C, Pedersen TP, Ojala K, Krølner R, Dzielska A, Ahluwalia N, et al. Fruit and vegetable consumption trends among adolescents from 2002 to 
2010 in 33 countries. The European Journal of Public Health. 2015; 25(2): 16-9.

7. World Health Organization. [Internet]. Switzerland: World Health Organization, 2018 [Updated: 2018 Dec 13; Cited: 2020 Apr 13]. Available from: https://www.who.int/news-room/factsheets/detail/adolescents-health-risks-and-solutions.

8. Svastisalee CM, Holstein BE, Due P. Fruit and vegetable intake in adolescents: association with socioeconomic status and exposure to supermarkets and fast-food outlets. Journal of Nutrition and Metabolism. 2012; 2012: 1-9.

9. Ziaei R, Shahi H, Dastgiri S, Mohammadi R, Viitasara E. Fruit and vegetable intake and its correlates among high-school adolescents in Iran: a cross-sectional study. Journal of Public Health. 2019; 28(3): 711-18.

10. Collese TS, Nascimento-Ferreira MV, de Moraes ACF, Rendo-Urteaga T, Bel-Serrat S, Moreno LA, et al. Role of fruits and vegetables in adolescent cardiovascular health: a systematic review. Nutrition Reviews. 2017; 75(5): 339-49.

11. Centers for Disease Control and Prevention. Fruit and vegetable consumption among high school students: United States, 2010. Morbidity and Mortality Weekly Report. 2011; 60(46): 1583-6.

12. World Health Organization. [Internet]. Switzerland: World Health Organization, Inc; 2003 [Updated: 2003 August 25; Cited: 2020 Apr 13]. Available from: https://www.who.int/dietphysicalactivity/publications/ f\&v_promotion_initiative_report.pdf.

13. Kant AK, Graubard BI. 20-Year trends in dietary and meal behaviors were similar in U.S. children and adolescents of different race/ethnicity, J Nutr. 2011; 141: 1880-8.

14. Levin KA, Kirby J, Currie C, Inchley J. Trends in adolescent eating behaviour: a multilevel crosssectional study of 11-15 year olds in Scotland, 20022010. Journal of Public Health. 2012; 34(4): 523-31.

15. Zaborskis A, Lagunaite R, Busha R, Lubiene J. Trend in eating habits among Lithuanian school-aged children in context of social inequality: three crosssectional surveys 2002, 2006 and 2010. BMC Public Health. 2012; 12: 52.

16. Esposito K, Kastorini CM, Panagiotakos DB, Giugliano D. Mediterranean diet and weight loss: meta-analysis of randomized controlled trials. Metabolic Syndrome and Related Disorders. 2011; 9(1): 1-12.

17. Mistretta A, Marventano S, Antoci M, Cagnetti A, Giogianni G, Nolfo F, et al. Mediterranean diet adherence and body composition among Southern Italian adolescents. Obesity Research \& Clinical Practice. 2017; 11(2): 215-26.

18. Gur K, Erol S, Kadioglu H, Ergun A, Boluktas R. The impact on adolescents of a Transtheoretical Modelbased programme on fruit and vegetable consumption. Public Health Nutrition. 2019; 22(13): 2500-8.

19. Erol S, Ergün A, Kadıoğlu H. Adölesanlarda MeyveSebze Tüketimi İçin Değişim Süreci Ölçeği: Güvenirlik ve Geçerlik Çalışması. Sağlık Bilimleri ve Meslekleri Dergisi. 2016; 3(2): 106-14.
20. Serra-MajeM L, RibaS L, NgO J. Food, youth, and the Mediterranean diet in Spain. Development of KIDMED, Mediterranean Diet Quality Index in children and adolescents. Public Health Nutrition. 2004; 7(7): 931-5.

21. Di Noia J, Schinke SP, Prochaska JO, Contento IR. Application of the transtheoretical model to fruit and vegetable consumption among economically disadvantaged African American adolescents: Preliminary findings. American Journal of Health Promotion. 2006; 20(5): 342-8.

22. Demirezen E, Coşansu G. Adölesan çağı öğrencilerde beslenme alışkanlıklarının değerlendirilmesi. Sürekli Tıp Eğitim Dergisi. 2005; 14(8): 174-8.

23. Aksoydan E, Çakır N. Adölesanların beslenme alışkanlıkları, fiziksel aktivite düzeyleri ve vücut kitle indekslerinin değerlendirilmesi. Gulhane Medical Journal. 2011; 53(4): 264-70.

24. Simmonds M, Llewellyn A, Owen CG, Woolacott N. Predicting adult obesity from childhood obesity: a systematic review and meta-analysis. Obesity Reviews. 2016; 17: 95-107.

25. T.C. Sağlık Bakanlığı. Türkiye Beslenme ve Sağlık Araştırması 2010: Beslenme durumu ve alışkanlıklarının değerlendirilmesi sonuç raporu. Ankara: Sağlık Bakanlığı Sağlık Araştırmaları Genel Müdürlüğü, Yayın (931); 2014.

26. Aygün Ö, Muslu GK. Vegetable and Fruit Consumption Behaviours of Secondary and High School Students. Turkish Journal of Family Medicine and Primary Care. 2017; 11(4): 245-55.

27. Lorson BA, Melgar-Quinonez HR, Taylor CA. Correlates of fruit and vegetable intakes in US children. Journal of the American Dietetic Association. 2009; 109(3): 474-8.

28. Lynch C, Kristjansdottir AG, Te Velde SJ, Lien N, Roos E, Thorsdottir I, et al. Fruit and vegetable consumption in a sample of 11-year-old children in ten European countries-the PRO GREENS crosssectional survey. Public Health Nutrition. 2014; 17(11): 2436-44.

29. Sahingoz SA, Sanlier N. Compliance with Mediterranean Diet Quality Index (KIDMED) and nutrition knowledge levels in adolescents. A case study from Turkey. Appetite. 2011; 57(1): 272-7.

30. Hadjimbei E, Botsaris G, Gekas V, Panayiotou AG. Adherence to the Mediterranean diet and lifestyle characteristics of University students in Cyprus: A cross-sectional survey. Journal of Nutrition and Metabolism. 2016; 2016(2): 1-8.

31. Peng W, Goldsmith R, Berry EM. Demographic and lifestyle factors associated with adherence to the Mediterranean diet in relation to overweight/obesity among Israeli adolescents: findings from the Mabat Israeli national youth health and nutrition survey. Public Health Nutrition. 2017; 20(5): 883-92.

32. Del Mar Bibiloni M, Pons A, Tur JA. Compliance with the Mediterranean Diet Quality Index (KIDMED) among Balearic Islands' adolescents and its association with socioeconomic, anthropometric and lifestyle factors. Annals of Nutrition and Metabolism. 2016; 68(1): 42-50. 